\title{
ANALISIS BIAYA PENGOBATAN PENYAKIT PARU OBSTRUKTIF KRONIK PASIEN RAWAT INAP RUMAH SAKIT UMUM DAERAH KABUPATEN SUKOHARJO
}

\section{COST ANALYSIS OF CHRONIC OBSTRUCTIVE PULMONARY DISEASE TREATMENT OF INPATIENTS IN DISTRICT OF SUKOHARJO GENERAL HOSPITAL}

\author{
Syafika Alaydrus \\ Sekolah Tinggi Ilmu Farmasi Pelita Mas Palu, Program Studi Diploma III Farmasi \\ Email : syafikaalaydrus39@gmail.com
}

\begin{abstract}
ABSTRAK
INA-CBG merupakan paket pembiayaan kesehatan berbasis kasus dengan mengelompokkan berbagai jenis pelayanan menjadi satu kesatuan. Tujuan penelitian ini untuk mengetahui, biaya rata-rata pengobatan, kesesuaian biaya riil dengan biaya paket INA-CBG, serta faktorfaktor yang berpengaruh terhadap biaya total pengobatan PPOK di RSUD Sukoharjo. Jenis penelitian ini adalah observasional dengan rancangan penelitian cross sectional menurut perspektif rumah sakit. Metode pengambilan data secara retrospektif. Subyek penelitian adalah pasien rawat inap yang menderita PPOK dengan faktor risiko dan komplikasi. Variabel penelitian meliputi karakteristik pasien meliputi umur dan jenis kelamin, faktor resiko dan komplikasi, dan biaya yang digunakan (medical cost dan non medical cost). Analisis data diuji menggunakan uji one sample T-Test, Anova, Kruskal-wallis test dan korelasi bivariat. Hasil penelitian menunjukkan usia $>60$ tahun dengan jenis kelamin lakilaki paling banyak menderita PPOK (76,2\%). Faktor resiko dan komplikasi terbanyak adalah cor pulmonale $(42,8 \%)$ dan lama rawat inap paling banyak adalah $<4$ hari $(58,8 \%)$. Faktor yang berhubungan dengan total biaya adalah lama rawat inap dan tingkat keparahan. Rata-rata biaya PPOK untuk tingkat keparahan berat sebesar Rp1.349.671,00 untuk ketiga jenis pembiayaan, untuk tingkat keparahan sangat berat dengan jenis pembiayaan umum, jamkesmas dan jamkesda berturut-turut adalah Rp1.051.955,5,00, Rp1.815.859,00 dan Rp1.589.706,5,00. Hasil penelitian menunjukkan bahwa rata-rata biaya pengobatan riil PPOK lebih rendah dan berbeda bermakna dengan biaya paket INA-CBG dengan nilai $\mathrm{P}$ 0,002 .
\end{abstract}

Kata Kunci : Analisis biaya, PPOK, INA-CBG

\begin{abstract}
INA-CBG was a packet-based health financing cases by classifying the various types of services into a single unit. Purpose of the study to determine the average cost of treatment, compliance the real cost with the INA-CBG package cost, and the factors that influence the total cost of COPD treatment at Sukoharjo hospital. This research was observational by cross sectional study design according to the hospital perspective. The data were collected retrospectively. The subjects were inpatients who suffer from COPD with risk factors and complications. The research variables were patient characteristics including age and sex, risk factors and complications, as well as the costs used (medical cost and non-medical cost). analysis of data was tested using one sample t-test and anova. The results showed that the most patients were above 60 years old, the most patients were COPD $(76,2 \%)$. The risk factors and most complications are cor pulmonale $(42,8 \%)$ and the most length of stay was $<4$ days $(54,8 \%)$. The factors influenced total cost were the length of stay and severity. The
\end{abstract}


average cost of COPD severe was Rp1,349,671,00, while the average cost of very severe COPD for general, Jamkesdaand Jamkesmas for patients were Rp1,051,955.5,00, $\mathrm{Rp} 1,815,859,00$ and $\mathrm{Rp} 1,589,706.5,00$ respectively. The results showed that average real cost of treating COPD are lower and significantly different to that is of INA-CBG P 0,002.

Keyword : Cost analysis, COPD, INA-CBG

\section{PENDAHULUAN}

Penyakit Paru Obstruksi Kronik (PPOK) merupakan istilah yang sering digunakan untuk sekelompok penyakit paru yang berlangsung lama dan ditandai oleh peningkatan resistensi terhadap aliran udara sebagai gambaran patofisiologis utamanya. Bronchitis kronik, emfisema paru, dan asma bronchial membentuk kesatuan yang disebut CPOD (Price, 2006).

Menurut Global Initiative for Chronic Obstructive Lung Disease (GOLD) 2010, tingkat keparahan PPOK berdasarkan nilai $\mathrm{FEV}_{1}$ (Forced Expiratory Volume) dan gejala terbagi empat tingkatan, yaitu tingkat 1 (ringan), tingkat II (sedang), tingkat III (berat), dan tingkat IV (sangat berat). Untuk memastikan tingkat obstruksi dan reversibilitas obstruksi, sebelumnya dilakukan uji dengan spirometer (Ikawati, 2011).

Pembiayaan merupakan salah satu faktor penting dalam melaksanakan pembangunan kesehatan. Sumber pembiayaan kesehatan saat ini meliputi pembiayaan yang berasal dari masyarakat termasuk swasta dan pembiayaan kesehatan dari pemerintah. Dari berbagai penelitian ditemukan bahwa pembiayaan kesehatan yang berasal dari pemerintah hanyalah $30 \%$ sedangkan dari masyarakat sebanyak $70 \%$ yang dilakukan secara langsung (direct payment) dari rumah tangga (out of pocket) dan melalui pihak ketiga yang masih relatif kecil seperti Askes, jamsostek (Setiati, 2005), dalam hal ini telah berubah nama menjadi Jaminan Kesehatan Nasional (JKN).

Rumah Sakit Umum Daerah Kota Sukoharjo melayani pasien Umum, jamkesda dan jamkesmas dan telah menjalankan program Indonesia Case Based Groups (INA-CBG) sejak tangga 1 Oktober 2010 sebagai landasan perhitungan biaya klaim pasien jamkesmas, tarif biaya PPOK berdasarkan INA-CBG adalah sebesar Rp2.491.944,00, Tujuan penelitian ini untuk mengetahui, biaya rata-rata pengobatan, kesesuaian biaya riil dengan biaya paket INA-CBG, serta faktor-faktor yang berpengaruh terhadap biaya total pengobatan PPOK di RSUD Sukoharjo, oleh karena itu pada penelitian ini akan dianalisis biaya pengobatan PPOK, serta dilihat kesesuaian biaya pengobatan pasien JKN KIS dengan pembiayaan kesehatan berdasarkan INA-CBG. 


\section{METODOLOGI PENELITIAN}

\section{A. Jenis dan Rancangan Penelitian}

Jenis penelitian ini adalah observasional dengan menggunakan rancangan penelitian cross sectional menurut perspektif rumah sakit. Metode pengambilan data dilakukan secara retrospektif yang diambil dari penelusuran dokumen catatan medik pasien dan biaya pengobatan pasien. Data pasien adalah data kuantitatif.

\section{B. Subyek dan Lokasi Penelitian}

Subyek penelitian yang digunakan adalah seluruh pasien rawat inap PPOK di RSUD Sukoharjo yang memenuhi kriteria inklusi yaitu pasien yang menderita PPOK dengan tingkat keparahan sedang dan berat, pasien memiliki rekam medis lengkap dan pasien dengan jenis pembiayaan jamkesmas, jamkesda dan umum.

\section{Metode Pengumpulan Data}

Tehknik pengambilan sampel yang digunakan adalah purposive sampling, yaitu dimana sampel yang memenuhi kriteria inklusi maka langsung diambil sebagai sampel dalam penelitian ini.

\section{Variabel Penelitian}

Variabel yang digunakan dalam penelitian ini adalah karakter demografi pasien yang meliputi usia dan jenis kelamin, intervensi obat yang diberikan, penyakit penyerta, lama perawatan dan biaya yang dibutuhkan (direct medical cost dan direct non medical cost)

\section{E. Bahan dan Materi Penelitian}

Bahan dan materi dalam penelitian ini adalah : (1) catatan rekam medik pasien PPOK yang termasuk dalam kriteria inklusi dan telah dikelompokkan berdasarkan diagnosis pasien. (2) data biaya pengobatan selama menjalani perawatan penyakit PPOK pada masing-masing pasien.

\section{F. Analisis Hasil}

1. Analisis deskriptif yaitu digunakan untuk mengetahui deskripsi dari karakteristik pasien, penyakit penyerta, lama perawatan, gambaran biaya ratarata.

2. Uji anova untuk mengetahui faktorfaktor yang menjadi prediktor utama biaya pengobatan pasien PPOK.

3. Analisis One sample T test digunakan untuk mengetahui perbedaan signifikan antara biaya riil pengobatan PPOK dengan biaya berdasarkan INACBG.

4. Uji korelasi dilakukan untuk mengetahui hubungan antara jenis kelamin, jenis pembiayaan, umur, Length of Stay (LOS), faktor resiko dan komplikasi terhadap biaya total pasien.

\section{HASIL DAN PEMBAHASAN}

Pada penelitian ini dilakukan analisis biaya terhadap pasien PPOK di RSUD Sukoharjo, PPOK merupakan angka kejadian yang cukup tinggi di RSUD Sukoharjo yaitu 128 kasus. Dari 128 kasus PPOK yang dijadikan sebagai populasi 
Alaydrus S, JIF Farmasyifa, 3(1): $51-61$

dalam penelitian ini, diperoleh 42 sampel

kasus PPOK yang memenuhi kriteria

inklusi.

\section{A. ANALISIS BIAYA PENGOBATAN PPOK}

1. Identifikasi Direct Medical Cost Pengobatan PPOK

a. Biaya Obat PPOK dan Biaya Obat lain

Tabel 1. Distribusi rata-rata biaya obat PPOK

\begin{tabular}{lllll}
\hline Jenis pembiayaan & Tingkat keparahan & N & Rata-rata Biaya Obat PPOK (Rp) \pm SD & P \\
& & 2 & $159.213,5 \pm 15.459,4$ & 0,344 \\
Jamkesmas & III & 6 & $116.524,3 \pm 110.616,8$ & \\
Jamkesda & & 3 & $183.870,7 \pm 88.772,8$ & \\
Umum & & 21 & $297.532,9 \pm 118.874$ & 0,014 \\
\hline Jamkesmas & IV & 4 & $188.984,3 \pm 128.793,6$ & \\
Jamkesda & & 6 & $138.893 \pm 38.059,1$ & \\
Umum & & & & \\
\end{tabular}

Tabel 2. Distribusi rata-rata biaya obat lain

\begin{tabular}{|c|c|c|c|c|}
\hline Jenis pembiayaan & Tingkat keparahan & $\mathbf{N}$ & Rata-rata Biaya Obat Lain $(\mathrm{Rp}) \pm \mathrm{SD}$ & $\mathbf{P}$ \\
\hline Jamkesmas & III & 2 & $250.672,5 \pm 106.301,4$ & 0,761 \\
\hline Jamkesda & & 6 & $277.338,7 \pm 66.898,1$ & \\
\hline Umum & & 3 & $368.302,7 \pm 242.039,9$ & \\
\hline Jamkesmas & IV & 21 & $476.672,1 \pm 281.615,5$ & 0,457 \\
\hline Jamkesda & & 4 & $386.372,3 \pm 172.104,6$ & \\
\hline Umum & & 6 & $345.741,7 \pm 171,259,7$ & \\
\hline
\end{tabular}


Analisis Biaya Pengobatan Penyakit Paru Obstruktif...

Distribusi rata-rata biaya obat PPOK dan biaya obat lain pada pasien rawat inap di RSUD Sukoharjo nilai P pada table 1 dan 2 pada tingkat keparahan berat menunjukkan tidak ada perbedaan antara tiap jenis pembiayaan. Nilai $\mathrm{P}$ pada biaya obat PPOK pada tingkat keparahan sangat berat menunjukkan nilai P 0,014 $(\mathrm{P}<0,05)$, hal itu menunjukkan bahwa ada perbedaan antara jenis pembiayaan umum, jamkesmas dan jamkesda. Hasil analisis menunjukkan bahwa perbedaan tersebut terletak pada jenis pembiayaan umum dan jamkesmas, tetapi tidak ada perbedaan antara umum dan jamkesda, serta jamkesmas dan jamkesda. Perbedaan tersebut disebabkan oleh lama rawat pada pasien jamkesmas lebih lama daripada pasien umum dan jamkesda, sehingga biaya PPOK untuk pasien jamkesmas lebih banyak diberikan.

\section{b. Biaya Jasa Sarana}

Tabel 3. Distribusi rata-rata biaya jasa sarana

\begin{tabular}{lllll}
\hline Jenis pembiayaan & Tingkat keparahan & N & Rata-rata Biaya Jasa Sarana (Rp) \pm SD & P \\
& & 2 & $195.475 \pm 2.510,2$ & 0,256 \\
Jamkesmas & III & 6 & $191.729,2 \pm 43.501,9$ & \\
Jamkesda & & 3 & $138.750 \pm 56.188,7$ & 0,017 \\
Umum & & 21 & $322.213,1 \pm 121.069,3$ & \\
\hline Jamkesmas & IV & 4 & $302.175 \pm 88.675,9$ & \\
Jamkesda & & 6 & $287.387,1 \pm 126.606,6$ & \\
Umum & & & & \\
\hline
\end{tabular}


Nilai $P$ pada tabel tersebut yang menunjukkan adanya perbedaan adalah pada tingkat keparahan sangat berat yaitu dengan nilai $\mathrm{P}$ 0,017 $(\mathrm{P}>0,05)$, dari nilai tersebut dapat dilihat terjadi perbedaan antara jenis pembiayaan. Jenis pembiayaan umum berbeda dengan jenis pembiayaan jamkesda dan jamkesmas, serta tidak ada perbedaan antara jamkesmas dan jamkesda. Perbedaan tersebut dipengaruhi oleh penyakit penyerta dan komplikasi pada pasien jamkesmas sehingga lama perawatan menjadi lebih lama. Lamanya perawatan tersebut membuat biaya rawat inap menjadi bertambah, biaya penunggu semakin banyak, serta tindakan medik mum seperti pemasangan infus dan injeksi, lebih banyak dilakukan terhadap pasien jamkesmas, sehingga menyebabkan adanya perbedaan biaya.

\section{c. Biaya Jasa Pelayanan}

Tabel 4. Distribusi rata-rata biaya jasa pelayanan

\begin{tabular}{lllll}
\hline Jenis pembiayaan & $\begin{array}{l}\text { Tingkat } \\
\text { keparahan }\end{array}$ & N & $\begin{array}{l}\text { Rata-rata Biaya Jasa Pelayanan (Rp) } \pm \\
\text { SD }\end{array}$ & P \\
\hline Jamkesmas & III & 2 & $177.450 \pm 68,942,9$ & 0,344 \\
Jamkesda & & 6 & $166.750 \pm 35.157,2$ & \\
Umum & 3 & $119.166,7 \pm 46.538,6$ & 0,050 \\
\hline Jamkesmas & IV & 21 & $314.423,8 \pm 111.381,5$ & \\
Jamkesda & & 4 & $310.350 \pm 118.282,1$ & \\
Umum & & 6 & $162.141,7 \pm 107.795,3$ & \\
& & & & \\
\hline
\end{tabular}

Biaya jasa pelayanan terdiri dari biaya pemeriksaan (visite dokter), biaya pelayanan non medik (keperawatan dan gizi), biaya konsultasi gizi, biaya laboratorium klinik, biaya radiodiagnostik, biaya IGD dan biaya tindakan medik umum rawat inap. Pada tabel terlihat nilai signifikasi yang sama dengan 0,05 pada tingkat keparahan sangat berat dengan nilai $0,050(\mathrm{P}<0,05)$. Hal ini menunjukkan bahwa tidak ada perbedaan bermakna dari ke 3 jenis pembiayaan tersebut. 
Analisis Biaya Pengobatan Penyakit Paru Obstruktif...

\section{d. Biaya Bahan dan Alat}

Tabel 5. Distribusi rata-rata biaya bahan dan alat

\begin{tabular}{lllll}
\hline Jenis pembiayaan & Tingkat keparahan & N & Rata-rata Biaya Total (Rp) \pm SD & P \\
& & & & 0,773 \\
Jamkesmas & III & 2 & $240.497,2 \pm 153,841,6$ & \\
Jamkesda & 6 & $169.625 \pm 51.474,9$ & \\
Umum & 3 & $169.333,3 \pm 79.041,6$ & 0,007 \\
& & 21 & $480.498,2 \pm 144.335,6$ & \\
Jamkesmas & IV & 4 & $476.825 \pm 54.867,2$ & \\
Jamkesda & & 6 & $245.791,7 \pm 89.984,2$ & \\
Umum & & & & \\
\hline
\end{tabular}

Biaya bahan dan alat adalah biaya bahan dan alat yang digunakan pasien pada laboratorium klinik, radiodiagnostik, IGD dan oksigen. Pada tabel tersebut nilai signifikasi yang $<0,05$ ada pada tingkat keparahan sangat berat nilai nilai P 0,007 (P $<0,05)$. Hal tersebut menunjukkan bahwa ada perbedaan dari jenis pembiayaan pasien. Perbedaan tersebut terletak pada jenis pembiayaan umum berbeda dengan jenis

\section{e. Distribusi Rata-Rata Biaya Direct Non Medical Cost Pengobatan PPOK}

Tabel 6. Distribusi rata-rata biaya Direct non Medical Cost Pengobatan PPOK

\begin{tabular}{lcc}
\hline Jenis pembiayaan & N & Rata-rata Biaya Total $($ Rp) \pm SD \\
\hline Jamkesmas & 23 & 22.500 \\
Jamkesda & 10 & 22.500 \\
Umum & 9 & 22.500
\end{tabular}

pembiayaan jamkesda dan jamkesmas, tetapi tidak ada perbedaan antara jamkesda dan jamkesmas. Sama seperti biaya jasa pasien jamkesmas dipengaruhi oleh penyakit penyerta dan komplikasi sehingga membuat lama perawatan pasien meningkat. Semakin lama pasien di rawat, maka bahan dan alat juga semakin banyak digunakan pelayanan dan biaya jasa sarana diatas, 
Direct Non Medical Cost adalah biaya langsung yang tidak berhubungan dengan pengobatan pasien seperti biaya administrasi dan biaya karcis. Biaya administrasi adalah rata-rata biaya pasien PPOK untuk administrasi rumah sakit meliputi biaya kartu tunggu, dan biaya kartu rekam medik, gambaran rata-rata Direct Non Medical Cost selama perawatan pada pasien PPOK adalah semua pasien dengan jenis pembiayaan besar biayanya adalah sama, hal ini dikarenakan tarif untuk biaya administrasi dan karcis pada semua pasien dengan jenis pembiayaan adalah sama.

\section{Biaya Total Rata-rata Pengobatan PPOK}

Tabel 7. Distribusi rata-rata biaya total pasien

\begin{tabular}{lllll}
\hline Jenis pembiayaan & Tingkat keparahan & N & Rata-rata Biaya Total (Rp) \pm SD & P \\
& & 2 & $1.023 .309 \pm 34.351,9$ & 0,480 \\
Jamkesmas & III & 6 & $921.967,2 \pm 203.525,4$ & \\
Jamkesda & & 3 & $986.923,3 \pm 448.613,9$ & \\
Umum & & 21 & $1.891 .340 \pm 705.693$ & 0,024 \\
& IV & 4 & $1.664 .707 \pm 412.552,6$ & \\
Jamkesmas & & 6 & $1.051 .956 \pm 315.561,6$ & \\
Jamkesda & & & & \\
Umum & & & & \\
& & &
\end{tabular}

Gambaran biaya total pengobatan PPOK yang meliputi direct medical cost dan non medical cost, nilai $\mathrm{P}$ pada tingkat keparahan sangat berat adalah 0,024. Hal ini menunjukkan bahwa, ada perbedaan pada jenis pembiayaann pada tingkat keparahan pasien sangat berat. Perbedaan tersebut disebabkan karena lama rawat pasien jamkesmas lebih tinggi, sehingga menyebabkan biaya jasa pelayanan, biaya jasa sarana, dan biaya bahan dan alat lebih tinggi dibandingkan dengan jenis pembiayaan jamkesda dan umum.
Tingginya ketiga biaya tersebut membuat biaya total pada pasien jamkesmas lebih tinggi, menyebabkan perbedaan dengan jenis pembiayaan lainnya. Biaya total ratarata untuk pasien dengan tingkat keparahan berat adalah Rp958.108,9,00 dimana untuk pasien dengan tingkat keparahan sangat berat tidak ada perbedaan, sedangkan untuk pasien dengan tingkat keparahan sangat berat biaya total rata-ratanya adalah untuk pasien umum Rp1.051.955,5,00, jamkesmas Rp1.815.859,00 dan pasien jamkesda Rp1.589.706,5,00. 
Analisis Biaya Pengobatan Penyakit Paru Obstruktif...

\section{Kesesuaian Biaya Total Rata-Rata Jamkesmas Dengan Biaya Paket INA-CBG}

Tabel 8. Distribusi rata-rata biaya total dengan paket INA-CBG

\begin{tabular}{lllll}
\hline Karakteristik & N & Tarif INA-CBG & Rata-rata Biaya Total $($ Rp) \pm SD & P \\
\hline Biaya Total & 23 & $2,491,944.00$ & $1.815 .859 \pm 717.861,4$ & \\
& & & & 0,002 \\
& & & \\
\hline
\end{tabular}

Dari tabel di atas dapat disimpulkan bahwa nilai signifikasi adalah 0,002 , berarti $\mathrm{P}<0,005$, berarti biaya riil pengobatan PPOK berbeda secara bermakna terhadap biaya pengobatan berdasarkan paket INA-CBG. Hal ini menunjukkan bahwa rumah sakit sudah melakukan efisiensi dalam menggunakan sarana kesehatan untuk memberikan perawatan terhadap pengobatan PPOK, sehingga besarnya biaya riil pengobatan pasien tidak melebihi tariff paket yang ditetapkan oleh INA-CBG. Salah satu faktor yang mempengaruhi hal itu adalah lama rawat pasien jamkesmas, dimana rata-rata lama rawat pasien jamkesmas adalah 5,43 hari. Rata-rata lama perawatan tersebut di bawah lama rawat ditetapkan oleh INA-CBG yaitu 7,58 hari.

\section{Hubungan Beberapa Faktor Yang Berpengaruh Terhadap Biaya Total}

Tabel 9. Hasil uji korelasi hubungan LOS, umur, jenis kelamin, penyakit penyerta dan jenis pembiayaan.

\begin{tabular}{lll}
\hline Karateristik & $\mathrm{N}$ & $\mathrm{P}$ \\
\hline Jenis Kelamin & & \\
Laki-laki & 34 & 0,234 \\
Perempuan & 8 & \\
\end{tabular}

\section{Usia}




\section{LOS}

$<7$

0,000

\begin{tabular}{lll}
\hline Jenis Pembiayaan & & \\
Jamkesmas & 23 & 0,001 \\
Jamkesda & 10 & \\
Umum & 9
\end{tabular}

\section{Tingkat Keparahan}

Berat

Sangat berat

\section{Penyakit penyerta}

Tidak ada

Tuberkulosis

Asma

Cor Pulmonale
0,106
Untuk dapat mengetahui adanya peran dominan beberapa variable terhadap biaya total digunakan uji korelasi. Uji ini dilakukan untuk mengetahui distribusi varians LOS, umur, penyakit penyerta dan jenis pembiayaan terhadap biaya total pada pengobatan PPOK. Table 17 tersebut menunjukan bahwa variabel LOS, tingkat keparahan, dan jenis pembiayaan berbeda signifikan terhadap variable biaya total. Hal ini berarti tingkat keparahan, mempengaruhi biaya total, pasien dengan tingkat keparahan yang lebih parah pasti akan mengkonsumsi lebih banyak obat, dan biaya jasa yang diperlukan, serta lama perawatan pasien akan semakin lama. Semakin lama pasien menjalani perawatan rawat inap, maka semakin bertambah biaya perawatan pasien. Umur, jenis kelamin, penyakit penyerta dan 
Analisis Biaya Pengobatan Penyakit Paru Obstruktif...

komplikasi tidak berpengaruh terhadap biaya total pengobatan PPOK.

\section{KESIMPULAN}

1. Rata-rata biaya riil pengobatan PPOK di RSUD Sukoharjo untuk pasien dengan tingkat keparahan berat Rp. 958.108,9, sedangkan untuk pasien dengan tingkat keparahan sangat berat adalah (umum Rp. 1.051.955,5, Jamkesmas : 1.815.859 dan pasien jamkesda Rp. $1.589 .706,5)$.

2. Biaya total pasien PPOK tidak dipengaruhi oleh jenis kelamin, umur, faktor resiko dan komplikasi, akan tetapi dipengaruhi oleh LOS dan tingkat keparahan.

3. Besarnya biaya riil pengobatan PPOK pada pasien Jamkesmas, lebih rendah dibandingkan dengan biaya paket berdasarkan INA-CBG.

\section{UCAPAN TERIMAKASIH}

Terimakasih kepada pihak RSUD Sukoharjo, yang telah mengizinkan peneliti untuk melakukan penelitian di RSUD tersebut.

\section{DAFTAR PUSTAKA}

Anonim., 2008., Pedoman Pengendalian Penyakit Paru Obstruktif Kronik (PPOK). Direktorat Jenderal Pengendalian Penyakit Dan Penyehatan Lingkungan, Direktorat Pengendalian Penyakit Tidak Menular. : Jakarta.
Anonim., 2009., Undang-Undang Republik Indonesia No. 44 Tahun 2009 Tentang Rumah Sakit :Jakarta

Ikawati Sullies., 2011. Penyakit System Pernapasan Dan Tatalaksana Terapinya. Yogyakarta: Bursa Ilmu

Global Initiative For Chronic Obstructive Lung Disease (GOLD), 2010., Global Strategy For Diagnosis, Management And Prevention Of CPOD.

Price, A.S., Lorraine. M.W., 2006., Patofisiologi Konsep Klinis Proses Proses Penyakit Edisi 6. Jakarta:Penerbit Buku Kedokteran EGC : Jakarta

Alaydrus, S. (2018)., Evaluasi Penggunaan Antibiotik Pada Anak Penderita Bronkopneumonia Di Rumah Sakit Provinsi Sulawesi Tengah Periode 2017. Jurnal Mandala Pharmacon Indonesia, 4(02), 8393.

Febriyani, N., \& Sidemen, I. G. N. (2012). Analisis Efektivitas Biaya Penggunaan Antibiotik pada Pasien Penyakit Paru Obstruktif Kronis (PPOK) Eksaserbasi Akut yang di Rawat Inap di Rumah Sakit Paru Jember. Febriyani, D. (2017). Analisis Efektivitas Biaya Penggunaan Salbutamol Dan Teofilin Sebagai Bronkodilator Pada Pasien Penyakit Paru Obstruktif Kronis (Ppok) Rawat Inap Di Rsud Dr. Soediran Mangun Sumarso Wonogiri Tahun 2016 (Doctoral Dissertation, Universitas Setia Budi Surakarta).

Sudoyo, A.W., Bambang. S., Idrus, A., Marcellus, S.W., Siti,S., 2009., Ilmu Penyakit Dalam. Perhimpunan Dokter Penyakit Dalam Indonesia.Jakarta 